\begin{tabular}{|c|c|c|c|}
\hline Article Info & REVI & DERLEME MAKALESİ & \\
\hline Title of Article & \multicolumn{2}{|c|}{$\begin{array}{c}\text { Urban rant phenomenon and the role of the } \\
\text { state in urban development process in } \\
\text { Turkey }\end{array}$} & \\
\hline $\begin{array}{l}\text { Corresponding } \\
\quad \text { Author }\end{array}$ & \multicolumn{2}{|c|}{$\begin{array}{l}\text { Dr.Öğr.Üyesi,Nihat KURT, Sakarya Uygulamalı Bilimler Üniversitesi, Hendek Meslek } \\
\text { Yüksek Okulu nkurt@subu.edu.tr }\end{array}$} & \\
\hline $\begin{array}{l}\text { Received Date } \\
\text { Accepted Date }\end{array}$ & \multicolumn{2}{|l|}{$\begin{array}{l}26.10 .2020 \\
27.12 .2020\end{array}$} & \\
\hline Author / Authors & Dr. Öğr. Üyesi Nihat KURT & ORCID: 0000-0003-3890-5895 & \\
\hline How to Cite & \multicolumn{2}{|c|}{$\begin{array}{l}\text { KURT, N.(2020).Türkiye'de Kentsel Gelişim Sürecinde Kentsel Rant Olgusu ve } \\
\text { Devletin Rolü, Kent Akademisi, Volume, 13, Issue 4, Pages-785-807 }\end{array}$} & $\begin{array}{l}\text { Kent Akademisi } \\
\text { Urban Academy }\end{array}$ \\
\hline
\end{tabular}

\title{
Türkiye'de Kentsel Gelişim Sürecinde Kentsel Rant Olgusu ve Devletin Rolü
}

Nihat KURT ${ }^{1}$

\section{ABSTRACT:}

During the urbanization process, the reproduction of the physical environment and the spatial transformation of cities have been an important part of urban development. Urban development is the production and organization of space, which includes many elements, including social and economic relations. The city continues its development through the mutual interaction of spatial components and physical and social environment elements that make up it as a system. In this respect, cities are also a product of social relations and a focus of technical, economic, cultural and actions. One of the important components that cannot be ignored in the spatial formation of cities that are reproduced over time and separated from each other is the phenomenon of rent. In this process, it is recognized that state interventions play a decisive role in the reorganization of urban spaces in a way that leads to rant, based on market demands and the ability to be a means of financial resources. Starting from these assumptions, practices conducted by state intervention in the formation and sharing of urban rents in the urban development process in Turkey and methods, constitute the framework of our study. In this context, by making use of the relevant literature; It is aimed to evaluate the role of the state in the formation and sharing of urban rents by explaining the processes of privatization, planning, transformation of urban areas, which are the main factors that create rent in our cities.

KEYWORDS: Rent, Urban Rent, Urban Transformation, Urban Planning, Urban Finance

\footnotetext{
${ }^{1}$ Dr.Öğr.Üyesi, Sakarya Uygulamalı Bilimler Üniversitesi, Hendek Meslek Yüksek Okulu
} 
ÖZ:

Kentleşme süreci boyunca, fiziksel çevrenin yeniden üretimi ile kentlerin mekânsal dönüşümü kentsel gelişmenin önemli bir parçası olagelmiştir. Kentsel gelişme, sosyal ve ekonomik ilişkileri de içeren birçok unsurun yer aldığı mekân üretimi ve organizasyonudur. Kent, bir sistem olarak kendisini oluşturan, mekânsal bileşenler ile fiziksel ve sosyal çevre unsurlarının karşılıklı etkileşimiyle gelişimini sürdürür. Bu açıdan kentler aynı zamanda, toplumsal ilişkilerin bir ürünü ve teknik, ekonomik, kültürel, eylemlerin bir odağıdırlar. Kentlerin zamanla yeniden üretilerek, birbirinden ayrışan mekânsal biçimlenmelerinde göz ardı edilemeyecek önemli bileşenlerden birisi de rant olgusudur. Söz konusu süreçte, kentsel mekânların ranta yol açacak biçimde yeniden örgütlenmesinde, piyasa talepleri ve finansal kaynak aracı olma vasfi temelinde devlet müdahalelerinin belirleyici rol oynadığı kabul edilmektedir. Bu varsayımdan hareketle, Türkiye'deki kentsel gelişme sürecinde kentsel rantların oluşumu ve paylaşımına yönelik devlet müdahalesiyle gerçekleştirilen uygulamalar ve yöntemler, çalışmamızın çerçevesini oluşturmaktadır. Bu kapsamda ilgili literatürden yararlanılarak; kentlerimizde rant oluşturan temel etkenler olan kamu mülklerinin, özelleştirilmesi, planlanması, kentsel alanların dönüştürülmesi süreçleri açıklanmak suretiyle, bunlar üzerinden devletin kentsel rantların oluşum ve paylaşımı üzerindeki rollerinin değerlendirilmesi amaçlanmaktadır.

ANAHTAR KELIMELER: Rant, Kentsel Rant, Kentsel Dönüșüm, Kentsel Planlama, Kentsel Finansman

\section{Türkiye’de Kentsel Gelişim Sürecinde Kentsel Rant Olgusu ve Devletin Rolü}

\section{Giriș}

Günümüzde kentler, tarihsel süreçleri boyunca ekonomik, siyasal ve toplumsal ilişkilerin belirlendiği ve gerçekleştiği mekânlar olmaları yanı sıra, sahip oldukları veya dönüştürüldükleri değer nedeniyle sermaye birikim süreçlerinin de önemli birer unsuru haline gelmişlerdir. Bu süreç boyunca kent yönetimleri de, gerek kent mekânlarının kullanım biçimlerine, gerekse üretim ve altyapılarına yönelik müdahale ve düzenlemelerle, bir taraftan kentsel hizmetlerin finansmanına katkı sağlamaya, diğer taraftan da sermayenin ekonomik büyüme kapasitelerini arttırma amacıyla kentleri şekillendirilmeye ve sürekli olarak yenilemeye çalışmaktadırlar. Böylelikle meydana gelen dönüşümün ortaya çıkardığı ekonomik hareketlilik etkinliğini, kentsel mekanların değeri üzerinden şekillenen rant olgusu ile temellendirmektedir. Ancak, rant oluşturan her türlü etkinliğin, eko-politik düzlemde tartışmalı bir işlev olarak görülmemesi için kentsel hizmetlerdeki amacın kamu yararı ilkesi sınırlarında kalmasına dikkat edilmesi gerekir. Aksi takdirde rant içeren masum etkinliklerin bile bir yozlaşma biçimi algısına dönüşebileceği göz ardı edilmemelidir.

Son yıllarda kentsel hizmetler nedeniyle kentlerin taşınır ve taşınmazlarında gerçekleştirilen doğal veya bilinçli düzenlemeler, yatırım kararları, yeni haklar gibi süreçlerle oluşan değer artışları, üzerinde düşünülmesi gereken önemli bir finansman kaynağına dönüşmüştür. Finansman ihtiyacının çok daha şiddetle hissedildiği günümüz kentleri için, hizmet anlayışındaki popülist 
yaklaşımlar, satın alma gücünün düşmesi, hizmet etkinliğinin sağlanamaması, vergi gelirlerinin yetersizliği, maliyetlerinin yüksek olması, hizmet ve kalite beklenti düzeyindeki toplumsal değişim gibi birçok neden, harcamaları karşılayabilme noktasında belediye gelirlerinin yetersizliğini ve merkeze bağımlı yapısını belirginleştirmiştir.

Diğer taraftan, yerel yönetimlerde, siyasi beklentilerin ekonomik etkinliklerin önüne geçmesi, diğer bir deyişle siyasi talebin, piyasa talebinden daha öncelikli hale gelmesi hizmet etkinliğini zayıflatıcı bir rol oynamıştır. Dolayısıyla, yerel yönetim ve çevre ilişkileri, ranta yönelik ekonomik işlevler ve her türlü kapasiteyi zorlayan nüfus artışlarıyla değişen kentsel süreçler bir taraftan, mevcut kent yapısına yönelik baskı yaratırken diğer yandan kentin yeni hizmet ihtiyacına yönelik beklentiyi önemli oranda arttırmıştır. Kentlerdeki rant olgusunun kaynak ihtiyacı temelli hareket noktasını önemli ölçüde bu etkenler şekillendirmektedir.

Kamunun, yönetsel paradigmasındaki dönüşüme bağlı olarak, kentsel rantın oluşum sürecindeki rolü de değişmektedir. Kamusal kararlarla kamu arazilerinden sağlanan ve özelleştirme, kentsel dönüşüm, kentsel planlama gibi müdahale araçlarıyla oluşturulan kentsel rantların, kentin gelişim sürecindeki etkisi öne çıkmaktadır. Ayrıca, kentsel rantların, kentin toplumsal alanındaki paylaşım süreçlerinin, kamu yararına uygun olmadan aktarımı temeline dayanan uygulamaları ise yozlaşma alg1s1 yaratmaktadir.

\section{Kentsel Rant Olgusuna Genel Bir Bakış}

Teknolojik gelişmeler, ekonomide yeniden yapılanma ve küreselleşme sürecinin, kentsel mekânların yapısal dönüşümünde önemli etkileri olmuştur. Bu süreçlerin yol açtığı özellikle kentsel büyüme baskısı sonucunda ortaya çıkan spekülatif ve hızlı değer artışları, kentin belirli bölgelerindeki araziler üzerinde yoğunlaşmıştır. Kent mekanlarının spekülatif kullanımlara konu olmaması ve haksız kazançların önüne geçilebilmesi için kentsel rantlara neden olan davranışların neler olduğunun bilinmesi gerekmektedir. Ayrıca, arazi değerlerinde görülen farklılaşmayı anlayabilmek, kentin sağlıklı bir şekilde gelişimini yönlendirebilmek için de önemlidir.

Günümüze kadar, kentsel toprakların kullanımları üzerinden şekillenen rant olgusunu açıklayan ve rant kavramını çeşitli tür ve isimler altında ele alan çok sayıda görüş ortaya atılmıştır. Ancak kent sermaye ilişkileri temelinde yapılmış olan çalışmalarda genel olarak, David Ricardo ve Adam Smith'in öncülüğünü yaptığı liberal rant kuramı ile Karl Marx'ın temsil ettiği rant kuramı arasında iki karşıt yaklaşım bulunduğu ve bu konudaki çatışmanın kentsel toprak rantı bağlamında onların takipçilerince devam ettirildiği görülmektedir.

Sözü edilen yaklaşımlardan ilki klasik ve neo-klasik kuramlar esas alınarak geliştirilen ve D. Ricardo'nun katkısıyla belirlenmiş olan "farklılık rantı" sınıflandırması ile, "konum" ve "yerleşme" kuramları adıyla, kent kuramlarına uyarlanmıştır. Bunlarda, genellikle firma ve bireylerin yerleşim yeri seçiminde, ek maliyetler nedeniyle merkeze uzaklığı dikkate alınmaktadır. D. Ricardo ve A. Smith'in temsil ettiği liberal kuramda rant, bir üretim faktörü olarak toprağın fiyatı üzerinden belirlenir. Klasik olarak adlandırılan bu iktisatçılara göre, arazi gelir sağlayıcı üç unsurdan biridir. "Emek", "sermaye" ve "arazi" den ibaret bulunan bu faktörlere sonradan "girişimcilik" de ilave edilmiştir. D. Ricardo, rantın temelini toprağın verimliliğine dayandırmaktadır. Ricardo’ya göre, toprağın kalitesi ve konumundaki farklılık sahip olması 
dolayısıyla topraklar arasındaki verim farkı, rantın ortaya çıkmasının nedenidir. Bu açıdan rant, her zaman eşit oranlardaki sermaye ve emeğin kullanımıyla elde edilen ürünler arasındaki fark olarak belirir. (Ricardo 1997, 61-65). A. Smith de toprağı, üretim faktörlerinden biri olarak görmekte, ücret ve karla beraber rantın, fiyatı belirlediğini söylemektedir. Smith, rantı incelerken topraklardaki verimlilik farkını, mülkiyeti, talep seviyesini, bireysel fiyatla piyasa fiyatı arasındaki fark gibi, rantın kaynağını, büyüklüğünü, oluşturulması konularını incelemektedir. Bununla birlikte, açıklamalarının rant teorisi açısından tutarlı olduğu söylenemez (Öztürk, 1992).

Rant konusunda öne çıkan temel yaklaşımlardan ikincisi ise, Marx'1n "mutlak rant" ve "tekelci rant" açıklamalarından yola çıkılarak geliştirilen ve liberal kuramın rant algısını özel mülkiyet vurgusu ile eleştiren Marksist yaklaşımdır. Marx, Ricardo'nun görüşlerini eleştirerek, toprak üzerindeki özel mülkiyet etkisini "mutlak rant” kavramı üzerinden açıklamaya çalışmıştır. Marx'a göre mutlak rantın kaynağı esasında, toprak üzerindeki özel mülkiyet tekelidir. Ona göre bu rant, ürün ortalama fiyatı üzerindeki artı değer olarak kapitalist anlayışın da temel bir unsurudur. Marx, diğer bir rant kategorisi olan farklılık rantını ise, verimli topraklarda üretilen ürünün pazardaki fiyatının (konum rantı), yine ayı ürünün değerindeki fazla ve toprağı işleme tekelinden kaynaklanan rant (verimlilik rantı) olmak üzere iki şekilde ele alınır (Marx, 1999, 118-120).

Marx'ın, çalışmalarında mekânın kullanım değeri sık olarak geçmekte, rant olgusu kentsel alanlarla ilişkilendirilmektedir. O, Özellikle nüfus artışının getirdiği konut talebi dışında, sabit sermaye gelişiminin, yapı kaynaklı rantları artırdığını, arsaya olan talep artışının, toprağın değerini de yükselttiğini belirtir. Bunun için dönemin Londra'sındaki yapı spekülasyonunu örnek göstererek "hızla büyüyen kentlerde, özellikle inşaatın bir sanayi olarak sürdürüldüğü Londra gibi yerlerde, yapı spekülasyonunun amacı konut değil, toprak rantıdır” görüşünü öne sürer (Marx, 2006: 679-681).

Marksist yaklaşımın sonraki dönemlerdeki temsilcilerinden biri olan ve bu konudaki görüşleri kente uyarlayan David Harvey ise, toprağın "kullanım değeri” ile "değişism değeri" arasındaki diyalektik ilişkiyi temel alarak toprak ve üzerindeki yapıların, kapitalist ekonomi anlayışındaki mallardan olduğunu ama bunların sıradan mallar olmadığını belirtir. Rantın belirleyiciliğini, kent topraklarında tekel konumundaki özel mülkiyet bakımından önemli görür. Bu rant daha çok toprak spekülasyonu biçiminde kendini gösterir. (Harvey, 2003: 146-148, 175).

Farklı1ık rantının, kentsel rant kuramlarına uyarlanması konusu uzunca bir süre tartışılagelmiştir. Bu kavramın öne çıkan bir açıklaması da neo-klasik ekonomi anlayışında VonThünen ve William Alonso modelleriyledir. Von Thünen'in kuramında rantın, tarımsal toprağın pazar kentine olan uzaklığından kaynaklanan farklı ulaşım maliyetlerine göre oluştuğu kabul edilmektedir. Bu nedenle, pazar kentine yakın mesafedeki toprak sahipleri, aynı zamanda konum rantına da sahip bulunmaktadırlar (Ertürk, 1997: 173-174).

Alonso ise, 1964 yılında yaptığı çalışmada, klasik yer seçimi ve rant teorilerinde olduğu üzere rant kavramını değer anlamı üzerinden geliştirmiştir. W. Alonso, 1826'da ortaya atılan Thünen modelinin, Neoklasik lokasyon teorisinin kökenini oluşturduğunu dolayısıyla kentsel rant kuramının von Thünen ile başladığını ileri sürer. Gerçekten de Thünen modeli, klasik rant kuramlarından farklı olarak, mekânsal olarak ele alınan ilk rant kuramıdır. Thünen, kentin merkezi etrafında gelişen tarımsal arazilerin kullanım özelliklerini, coğrafi uzaklık, ulaşım maliyetleri ve 
toprak fiyatlarını dikkate alarak açıklamıştır. Thünen'in kuramında pazar kentine yakın konumdaki tarımsal toprak sahipleri, konum rantına sahiptirler (Ertürk, 1997:174-175). Alonso'ya göre, arazi değeri kentteki arazi kullanım biçimi ile yakından ilgilidir. Ona göre, nüfus artışı, arazi talebindeki artışla birlikte arazi değerlerini yükseltmektedir. Alonso, aynı kuramsal yaklaşımı içerisinde, kentsel topraklar ile tarımsal toprakları bütüncül olarak ele almaya çalışmış ve bu konuda tarımsal topraklardaki rant olgusu için Ricardo'nun görüşlerinden yararlanmıştır. (Alonso, 1968: 1-15)

Rant olgusu üzerine yapılan çalışmalardan biri de Rosenthal ve Helsley'in araştırmasıdır. Bu araştırma, şehrin yeniden gelişimini dengeli bir modelle ele alarak gösteren ilk dikkatli inceleme olmasının yanı sıra, imarlı bölgelerdeki boş arazilerin değerinin yeniden kazanılması maliyetinin metodolojisini de göstermektedir. Vancouver'da satılan ve yeni gelişen boş ve imarlı araziler karşılaştırılmıştır. Boş arazilerin değerlerinin, kullanımdaki arazi değerlerini geçmesi durumu, çok büyük ölçüde iskânın yeniden gelişimi hipotezini desteklemiştir (Rosenthal ve Helsley, 1994:182200).

Bir başka öne çıkan araştırma da Miles, Berens ve Weiss' in çalışmasıdır. Bu araştırmada nüfus verileri kullanılarak ulusal, bölgesel ve yerel pazarlarda yer alan belirli arsalardaki arazi değerini etkileyen faktörler incelenmiştir. Uygun altyapıya sahip olan yerlerdeki geliştirilebilir arazilere yönelik talep, arazi fiyatlarını hızla arttırırken, aynı şekilde yüksek yoğunlukta ticari ve konut kullanımlarını da arttırmaktadır. Arazi fiyatlarının yüksek oluşu ve boş arazilerin azlığı gibi sebepler, zaman içerisinde birçok imalatçıyı, geride imalat kullanımı için potansiyeli düşük boş yapıları bırakarak metropoliten alanlar dışındaki küçük kasabalara yöneltmiştir. Bununla birlikte, metropoliten alanlarda artan nüfus yoğunluğunun etkisiyle coğrafi açıdan dişa yönelik genişleme devam etmektedir (Miles, Berens ve Weiss, 2000:17-33).

2001 yılında Dale-Johnson ve Brzeski tarafından gerçekleştirilen diğer bir önemli araştırmayla da, dönüşmekte olan bir ekonomideki kentsel arazi piyasasının gelişimi üzerine yeni bir bakış açısı getirilmektedir. Polonya'daki arazi kullanım kararlarının artık pazar güçleri tarafından alınmaya başlanıp devam ettirildiği yeni ekonomik dönemin incelendiği bu çalışmada zamanla arazilerin değerini oluşturan fonksiyonların her birinin eğiminin yukarı yönlü değişimini ortaya konmuştur. $\mathrm{Bu}$ sonuçta, ulaşım ve firsat fiyatlarındaki gerçek artışların etkili olduğu ve ayrıca, altyapısının mevcut olmasının parsel değerinin üzerinde büyük ölçüde etkisinin bulunduğu gösterilmiştir (Dale, Johnson ve Brzeski, 2001: 307-334).

Gelinen noktada "kentsel rant" olarak ifade edilen olgu esasında, kaynağını kentsel yaşamın veya kent ekonomisinin oluşturduğu rantların tümünü içermektedir (Umay, 2006:109-110). Günümüzde daha çok olumsuz, arzu edilmeyen bir olgu biçiminde görülmektedir. Bu durumun arka planında yatan temel faktörler; rekabet odaklı piyasa mekanizmasının elverişli bir ortam sunması, haksız kazanç, düzensiz kentleşme, ortaya çıkan rantın paylaşımında kamu yararından çok, özel girişimcilerin ve diğer piyasa aktörlerinin istifade etmesi, üretilen projelerde hedefin öncelikle insan yararı değil, kâr olması biçiminde sıralanabilir (Topçu, 2017: 46).

Kentsel rant olgusunun gerçekleşme şekline baktığımızda ise, daha çok kent toprakları üzerindeki sermaye yatırımları sonucunda meydana gelen değer artışlarının oluşturduğu cazibeyle, mülkiyetin el değiştirmesi biçiminde oluştuğu görülmektedir. Kentsel alanlardaki taşınmaz mülkler, gerek 
konumundan gerekse sunulan imkân ve hizmetlere olan mesafesi sayesinde değerlenmektedir. Diğer bir ifadeyle kentsel rantlar, bir taraftan kamunun eylem ve işlemleri sonucunda ortaya çıkarken, diğer taraftan kentsel toprakların bulundukları yerin niteliğine yönelik gerçekleştirilen müdahaleler nedeniyle oluşan değer artışlarından kaynaklanmaktadır (Ökmen ve Yurtsever, 2010: $62)$.

Türkiye'deki kentsel rant olgusu konusunda genel olarak öne çıkan görüş ise; kamu mülkiyetinde olan toprakların nitelik değiştirerek özel mülk niteliğine dönüşmesi ve bu süreçte meydana gelen ranta sahip olunması şeklindedir. Dolayısıyla kentsel rantlar, kamusal karar, işlem ve eylemlerle, piyasa mekanizması ve imar haklarıyla oluşturulan artı değerin bir ürünüdür. Bu alanda yapılan her türlü hukuki düzenleme, sürecin bir parçası niteliğinde ya yeni rantlar oluşturmakta ya da mevcut rantlara meşruiyet kazandırmaktadır (Turan, 2009: 14-16). Nitekim, gecekondulara yönelik ilk af yasaları ile başlayan, kamu arazilerinin özel arazilere dönüşümü süreci, kentlerdeki kamu arazilerini özel sektör lehine azaltmıştır (Şenyapılı, 2014: 337)

Yapılan yatırımlarla toplumsal refahın görece daha fazla hissedildiği mekânlar olmasına karşın kentlerde, bu refahın toplumun tüm katmanlarına yaygınlaşmaması, istihdamın yeterli düzeyde gerçekleşmemesi, toplumsal eşitsizliklerin yol açtığ problemlerin giderilmesindeki önemli eksikliklerdir. Ayrıca nüfus artış hızına göre artan konut talebinin yeterince karşılanamaması ve buna bağlı olarak arsa spekülasyonunun öne çıkması gibi faktörler de kentsel rant olgusunu besleyen nedenler olmuştur (Turan, 2009: 48-49).

Ülkemizde kentleşme nedenleri arasında yer alan sanayileşme ve bunun yol açtığı hızlı nüfus artışının bir yansıması olarak karşımıza çıkan yaygın rant görünümleri, daha çok gerçekleştirilen imar değişiklikleri veya sunulan hizmetlerden kaynaklanan artı değerle şekillenmektedir. Nitekim bu kapsamda kamusal mülkiyete ait taşınmazlar üzerinde, kamusal imkânlar kullanılarak yapılan plan değişiklikleriyle yerleşim alanları, yeni ulaşım sistemleri ve ağlar oluşturulmakta, alt yapı ve çevreye yönelik kentsel düzenlemelerle de yeni kentsel dönüşüm alanları gerçekleştirilmektedir. Yapılan uygulamalarda rantın bir tarafı olarak devlet, özel girişim lehine çıkar avantajı yaratmakta ve bu avantajın kar gerçekleşmesi ve paylaşımı da söz konusu olmaktadır (Boratav, 2000: 141). Bir başka deyişle devlet, piyasanın doğal süreci içerisinde kendi aktörlerinin tasarrufları sonucunda oluşmayan, toprak üzerinde çeşitli müdahaleleriyle oluşturduğu değerin paylaşım ilişkilerini düzenleme işlevlerini yürüterek toplumun ve sermayenin yeniden üretimine katkı sağlamaktadır (Harvey, 2003: 248-250).

Kent ölçeğinde veya merkezi ölçekte yapılacak hizmetlere ilişkin yönetimlerce alınacak kararlar, oluşacak rantın düzeyini belirleyebilmektedir. Ancak rantın kaçınılmaz olarak ortaya çıkmasından çok o rantın ne şekilde veya kimler tarafından kullanılacağı konusu suiistimale açık bir alan haline gelmektedir. Oysa burada dikkat edilmesi gereken husus adil, objektif hizmete dönük kararlarla, getirisinden kentte veya bölgede yaşayanların mümkün olan en geniş ölçüde, birlikte yararlanacağı yatırımların gerçekleştirilmesidir. Diğer bir deyişle, ortaya çıkarılan rantın, serbest piyasa şartlarında kamu yararına daha uygun hale getirilebilmesidir (Sevindik, 2009: 53).

Kentin gerek mekânsal gerekse hizmet açısından planlanmasıyla, yapılacak düzenlemelerden oluşacak rantın, toplumsal dokuyu tahrip edecek çıkar çatışmalarına, ayrışmaya yol açmaması, kentte bütünlük ve dengeyi gözetmesi hedeflenmelidir. Hizmete yönelik yatırım kararlarında ve 
kentin içinde yaşayanların konforunun daha iyiye dönüşümünde toplumsal refahı, uyum ve düzeni hedef alan gerçek anlamda "kamu yararı" anlayışıla hareket edilmelidir. Oysa 1980'lerden sonraki neo-liberal olarak nitelendirilen süreç, özellikle planlama anlayışlarındaki dönüşüm ve planlama mevzuatındaki değişiklikler, kamu yararını bu alanda temel değer olmaktan çıkarmaya başlamıştır. Bu süreçte yaşanan hızlı kentleşme, özellikle büyük kentlerde, bireysel menfaatlerle kamu yararı arasındaki çelişkili durumu görünür kılmıştır (Şengül, 2007: 105-127; Keleş, 2000: 114).

Gelinen aşamanın bir sonucu olarak piyasa ekonomisinin canlanması, kaynakların kıt olduğu ortamdaki malların değişimi üzerinden yapılan her türlü tahsis sonucunda gerçekleşmiştir (Harvey, 2003: 68). Kamusal mülklerin satışının kentsel alanlardaki piyasa üzerindeki etkisi de bu koşullardan kaynaklanmaktadır. Kentsel mekânlardaki kamu mülklerinin varlığı, sermayeye yönelik muhtemel pozitif katkıları dolayısıyla ekonomik açıdan dikkate değer bir anlam ifade etmektedir. Kentlerin özellikle merkezi konumundaki topraklarının talebe göre kıt bir kaynak oluşu bunları, rant dolayısıyla önemli bir kaynak hale getirmektedir. $\mathrm{Bu}$ toprakların, talebi oluşturan özel mülk sahiplerine maliyeti, diğer yerlere göre epey yüksek olduğundan, bir sonraki aşamada gerek mülklerin satın alma bedellerine gerekse kira bedellerine değer arışı olarak yansımaktadır. Tasarlanan kamusal alanlar, tüm mekânlar gibi 'kullanım değeri' ve "lokasyonu" ve tercih edilme kapasitesi ile kendi değerini ortaya koymaktadır. Söz konusu değer, kentli kullanıcılar tarafından benimsenip, onaylanması ölçüsünde belirlenmiş olmaktadır (Akyıldız, 2020: 197).

Kent merkezleri, nüfus yoğunluğunun yüksek olduğu ve buna bağlı olarak da ekonomik ilişkilerin canlı olduğu mekânlardır. Kentsel büyümedeki hızlı artışın sürmesi, toprağın konumunu değiştirmekte, alınan kararlarla dönüştürülen yeni kullanım biçimleri toprağın değerini daha da arttırmaktadır (Ertürk ve Sam, 2009:160-161). Öte yandan, üretilen malın değerinin arz-talep çerçevesinde belirlenmesi temelinde, ekonomik ve hizmete en kolay ulaşılabilecek olan kent merkezlerindeki, yani "pazara" en yakın mesafedeki taşınmaz mülklerin değeri de en yüksek olmaktadır (Evans, 1983: 120).

Kent topraklarının bütünü içindeki konumuna bağlı olarak zaman içerisinde sürekli olarak değişebilen ve çok sayıda işleve sahip olan bu mülklerin değeri, sahiplerinin iradesi dışındaki etkilerle de değişime açık hale gelmektedir. (Kartal, 25-28) Kent alanlarında gerçekleştirilen, imar planı değişiklikleri ve kat artışları, altyapı ve ulaşım sistemlerinin yenilenmesi ve gelişimi, toplu konut projeleri, sosyal konut uygulamaları, kentsel dönüşüm, yenileme, koruma projeleri gibi imar düzenlemelerini içeren yönetsel kararlar mekânsal değerlerin yükselmesine ve rantlara zemin hazırlamaktadır. $\mathrm{Bu}$ süreç, tarımsal arazilerin kent toprağına dönüşümü, imar hareketlerinin başlaması, arazilerin belediye sınırlarına katılması ve imara açılması, alt yapının hazırlanması kamusal hizmet alanlarına ve tesislere kavuşturulması gibi bir dizi faaliyeti içermektedir (Keleş, 2013: 543). İmar planları ile yapılan yeni düzenlemelerin yanı sıra kente yönelik her türlü müdahalenin beraberinde getirdiği değer artışları, yeni hizmetlere sağlayacağı mali katkının yanı sıra, sunulan mevcut hizmetlerin kalitesini de arttıracaktır. Ne var ki bu katkılar, herkesin tercih edebileceği bir şey olsa da, önemli olan oluşan rantın sahip olunan mülkiyette haksız değer edinme aracı olmaktan çıkarılmasıdır.

\section{Kentsel Dönüşüm Sürecinde Bir Yöntem Olarak "Rant"}


Kentsel dönüşüm, kentin gerek fiziksel gerekse toplumsal yönlerden değişimini içerir. Fiziksel açıdan gerçekleşmesi istenen yapısal değişimi; toplumsal açıdan ise, mevcut halleriyle arzu edilmeyen kentsel mekânların belirli toplumsal aktörler marifetiyle dönüşüme tabi tutulmasıdır (Şahin, 2003: 92). Mekânın insanlar üzerindeki etkisi dolayısıyla mevcuda göre çok daha iyi mekânsal ve kentsel çözümler kamu yararı içerenlerdir. Bu kentsel dönüşümün gerekliliği için de doğru bir argümandır. Ancak dönüşüm yapılan alanlardan elde edilen rantın kamu yararına kullanılması ve ülke ekonomisine en büyük katkıyı yapması oldukça önemlidir (Topçu, 2018: 39).

Dünya genelinde kentsel dönüşüm önemli bir ihtiyaç neticesinde ortaya çıkıp gelişmiştir. İlk olarak 1750'lerde Sanayi Devrimiyle birlikte kırdan kente doğru yaşanan plansız göçler, sanayi yoğunluğu olan kentlerde aşırı nüfus artışına neden olmuş, bunun etkisiyle de çarpık kentleşme ve sağlıksız yaşam alanları gerçeğiyle karşılaşılmıştır. Bunlara yönelik çözüm kentsel dönüşüm uygulamalarıyla ortaya konmaya çalışılmıştır. Esasen, her ülkenin ve kentin geçirdiği kentleşme sürecinin temelinde yatan, buralarda yaşayan insanların kültürlerinin, sosyal yapılarının ve ekonomik durumlarının farklı oluşu nedeniyle, gerçekleştirilen kentsel dönüşüm uygulamaları da değişiklik göstermektedir (Y1lmaz ve Bozdoğan, 2018:232-434)

Türkiye'de 1950'lerden itibaren kentsel sorunlarla karş1laşılmaya başlanmış ise de, kentsel dönüşüm konusunun hükümet politikalarına girmesi, 1980'li yıllardır. Bu dönemde kentsel dönüşümden Türkiye'nin yeni neo-liberal kentleşme aracı olarak yararlanılmaktadır. Bu konudaki ilgi, kentsel rant piyasasının en yüksek getiriyi sağlayan en cazip alanlarına yönelmektedir. Kentsel dönüşüm projelerinin başlıca gelir kaynağı hâline geldiği uygulamalar nedeniyle Türkiye'deki kentsel dönüşümün gelişimi devlet eliyle piyasa odaklı olarak tanımlanmaktadır (Güzey, 2012: 70).

Ülkemizde dolaylı düzenlemelerin varlığı çok daha eskiye gitmekle beraber kentsel dönüşümle doğrudan ilgili düzenlemelerin geçmişine baktığımızda bu konuda iki düzenleme öne çıkmaktadır. Bu düzenlemelerden 2003 yılında 4966 sayılı yasayla, Toplu Konut İdaresi'ne kentsel yenileme konusunda yetki ve finansman imkânları verilmiş; 2004 yılında ise 5162 sayılı yasayla, İmar Bakanlı̆̆ı'nın gecekonduların tasfiyesiyle ilgili yetkileri TOKI'ye devredilmiştir. Sonrasında da, TOKI'nin kentsel gelişme ile ilgili yetki alanı hızla genişlemiştir. Kentsel rant alanları yaratma amacina dönük kentsel dönüşüm projelerinin Türkiye'nin tüm kentlerinde gündeme girmesi ise, yerel yönetimlerin kentsel dönüşüm projeleri hazırlama ve uygulamalarının önünü açan yasal düzenlemeler olan, 2005 yılında çıkarılan 5393 sayılı "Belediye Kanunu” ve 5366 sayılı "Yıpranan Tarihi ve Kültürel Taşınmaz Varlıkların Yenilenerek Korunması ve Yaşatılarak Kullanılması Hakkında Kanun” ile 2012 yılında çıkarılan 6306 sayılı "Afet Riski Altındaki Alanların Dönüştürülmesi Hakkında Kanun” la olmuştur (Özgül, 2020: 67). Bu kanunun amacı; afet riski altındaki alanlar ile bu alanlar dışındaki riskli yapıların bulunduğu arsa ve arazilerde, fen ve sanat norm ve standartlarına uygun, sağlıklı ve güvenli yaşama çevrelerini teşkil etmek üzere iyileştirme, tasfiye ve yenilemelere dair usul ve esasları belirlemektir. Bu tür riskli alanlar, Çevre ve Şehircilik Bakanlığı, TOKİ ya da Belediyeler tarafından belirlenirken tüm yetki yine bu kurumlara devredilmiştir (Güzey, 2012: 74)

Kentsel dönüşüm için "rant”, gerekli bir unsur olmamasına karşın, kamu ekonomisinin verimliliği açısından sadece kamu kaynaklarıyla dönüşümün gerçekleştirilmesi kamu hizmetlerinin etkin sunumu açısından zorlayıcı bir durumdur. Bu yüzden yönetimler kentsel dönüşümün kesin olarak 
gerekli görüldüğü yerlerde bu işlemi, rant getirisi olan projelerle gerçekleştirmektedirler. Ancak, gerçekleştirilmesi ile rantın ortaya çıkması söz konusu olmayan ancak yapılması gerekli olan kamusal nitelikli diğer projeler de kamunun hizmet arzında önemli yer tutmaktadır. Bu türden rant içermeyen projelerin kamusal kaynaklarla finanse edilmesi kaçınılmazdır. Zaten kıt olan kamusal kaynakların etkin ve verimli bir biçimde yönetmek durumunda olan yönetimlerin, her türlü olumsuz algıya rağmen kentsel dönüşümlerde, doğrudan kamu kaynaklarıyla finanse edilmesine dönük projeler yerine rant oluşturabilme potansiyeli olanları tercih etmesi ekonomik düşünce açısından rasyonel bulunmaktadır. Kaldı ki kamusal kaynaklar yeterli olsa bile, kentsel dönüşüm projelerinin gerçekleştirilmesinde özel sektörün de projelerde yer alması projenin niteliğinde ve hızında olumlu bir katkı sağlayacaksa, kamu-özel ortaklığı yöntemi tercih edilmelidir (Ulutaş, 2005: 60)

Kentsel dönüşümle fiziksel iyileşmenin yanı sıra kentin ekonomik açıdan canlanması da amaçlanmaktadır. Böylece kentsel dönüşüm, kentlerde hem niteliksel hem de yapısal değişime yol açmaktadır (Tekeli, 2003: 3-7). Kamu sektörünün finansmanında zorluk bulunan projelerde ifade edildiği gibi özel teşebbüslere ihtiyaç ortaya çıkmaktadır. Bu kapsamda; inşaat firmaları, pazarlama, emlak şirketleri, finansman kuruluşları, mülk sahipleri ve yatırımcılar yer almaktadır. Özel sektör, kentsel dönüşüm uygulamalarına; proje hazırlama, gerçekleştirme, işletme, finansal destek gibi konularda katkı sağlayabilmektedir. Dolayısıyla özel sektör açısından ticari menfaat ya da karın işin cazip unsurunu oluşturması nedeniyle dönüşüm çalışmalarına özel sektörü katabilmek için, kentsel dönüşüm projelerinde onlara fayda sağlayacak firsatlar sunulması gerekmektedir (Kutlu, 2004: 267). Hatta bunun da ötesinde, sadece piyasa aktörlerinin içinde bulunduğu ve bunların yer aldığı süreçlere bırakılmayan, kentteki tüm kesimleri kapsayan bir kentsel dönüşümün yaşam standardına olumlu yönde etki eden önemli bir değişken olduğu da gözlenmektedir (Sadioğlu, 2020: 901).

Yatırım ve müdahalelerle, kentsel toprak üzerinden oluşturulmaya çalışılan yeni değer çerçevesinde yürütülen kentsel dönüşüm uygulamaları, kente yönelik gerçekleştirilen en temel müdahale araçlarından birisi haline gelmiştir (Göksu ve Bal, 2010: 257). Kentsel dönüşüm ile hedeflenen süreç, eskisinden çok daha iyi yaşam standartlarını içeren farklı kullanım alanlarıyla yeni bir kentsel düzen oluşturmaktır. Ulaşımdan, konut alanlarına, ticaret alanlarından yeşil alanlara bir bütün halinde eskisinden çok daha kaliteli bir çevreyi oluşturmak başlıca hedeftir. Dönüşüm öncesi bu alanlardaki çöküntü ve düzensizliğin olumsuz etkileri, nasıl ki kentin tamamında ve yönetiminde sıkıntı oluşturuyorsa, hedefin gerçekleşmesi sonrasındaki getiriden de doğrudan hak sahipleri yanında tüm kentin dolaylı da olsa yararlanması bir kentsel dönüşüm projesi üretiminden beklenen en önemli fayda olmalıdır. Dolayısıyla, kentsel dönüşüm rant aracı olarak görülmemeli çünkü rant, projenin temelinde yer alan hareket noktası değil sonucudur. Kaliteli çevre dokusu oluşturması nedeniyle dönüşüm projelerine talep olmaktadır (Topçu, 2017, 47). Diğer bir ifadeyle bu uygulamaların yaygınlaşmasındaki asıl etken, aynı zamanda daha kaliteli ve eskiye oranla çok daha yüksek standartlardaki yeni yaşam alanlarına yönelik piyasa talebinde meydana gelen artıştır. Dönüşümün kentsel dokuya yaptığı yeni olumlu katkının toplumsal taleple ölçülebilir maddi değer olarak karşılık bulmasıdır.

Ne var ki son yıllarda fiziksel, ekonomik olarak çöküntü alanlarına dönüşen kent merkezlerinin yeniden düzenlenerek ayağa kaldırılması için gerçekleştirilen kentsel dönüşüm uygulamalarının, yeni yasal düzenlemelerle sağlanan yetki ve imkânlar çerçevesinde amacının dışında kullanılmaya 
başlandığı gözlenmektedir. $\mathrm{Bu}$ konudaki olumsuz değerlendirmelerin toplumda giderek yaygınlaşması, kamuoyunda kentsel dönüşüme dair güveni ve desteği azaltmaktadır (Sadioğlu, 2020:881). Bu tür bir alg1 açısından ise, kentsel dönüşümün özünde, sağlıksız yapılaşmış kentsel alanlar ve nüfus sorunlarına çözüm bulmaktan çok, bu tür alanların yenilenerek kentsel arsa piyasasına katılması yer almaktadır (Aksoy ve Güzey Kocataş, 2017: 291).

Çoğu zaman kentlerde spekülasyonun yol açtığı değer artışlarının temelinde; gerçekleştirilmekte olan kentsel dönüşümün ve finansman uygulamalarının önemli bir yeri bulunmaktadır. Ayrıca kentin bütünü göz ardı edilerek bazı bölümlerinin hatta parsel düzeyinde planlanması, mülkiyeti devlette olan toprakların özel mülkiyete geçirilmesi veya özel mülkiyette bulunanların da el değiştirmesi diğer nedenler arasında yer almaktadır (Turan, 2009: 97).

Gelişmiş ülkelerdeki kentsel dönüşüm uygulamalarında, ekonomik gelişime katkı sunan çözümler göze çarpmaktadır. Ancak Türkiye'de bu durum ne yazık ki farklıdır. Dönüşüm uygulanan alanlarda, üretilen ticari mekânların ekonomik etkinliği zayıf kalmaktadır. Kentsel dönüşüm uygulamaları ekonomik gelişmeye yönelik kazanımlardan daha çok konut ağırlıklı bir yapılaşma sergilemektedir. Üretimi temel alan, katma değer yaratarak ekonomik refahı önceleyen kent ekonomisinin oluşturulması ve bunun sürdürülebilir kılınması gerçeği göz ardı edilmektedir. Öte yandan ülkemizde, kentsel mekân, kentsel değerleri muhafaza noktasından hareketle, insan ve kültür gerçeği birlikte yeterince ele alınmamaktadır (Yaman ve Şahinbaş, 2017: 73).

Halkın anlayışı ve katkısı sağlanmadıkça kentsel dönüşüm plan çalışmaları ve uygulamaları başarılı olamayacağından olumsuz davranışlarının önüne geçmek için dönüşüm gerçekleştirecek kent yönetimlerinin halkla ilişkilere önem vermesi gerekir. Katılımcı kentsel dönüşüm planları, kent kimliğinin korunmasında güvence sağlayarak, doğayı, çevreyi, yeşil alanları tarihsel ve kültürel varlıkları koruyucu niteliğiyle öne çıkmalıdır (Doğan, 2015:540).

Gelinen noktada giderek kentlerde rant oluşturan önemli bir alan haline gelen kentsel dönüşüm ve finansman projeleri, konut üretimi ve konut finansman sisteminde dahi değişime neden olmuştur. Geçmişte, konut ihtiyacının, kamu kuruluşlarınca arsa ve kredi desteği, konut kooperatifleri yoluyla giderildiği sistem artık değişmiştir. Özellikle, konut piyasasına dayalı olarak devlet ve özel mülk niteliğinde bulunan kentsel topraklar üzerinde taşınmaz yatırım ortaklıkları ve finans kuruluşları önemli aktörler haline gelmişlerdir. Kentin boş arazilerinde ya da özel mülk niteliğindeki büyük alanlarda sermaye şirketleri, proje ve uygulamaları kendileri yaparken, kentteki proje yapılması risk oluşturan gecekondu bölgelerinde devreye TOKİ girmektedir (Şişman ve Kibaroğlu, 2009: 3-4).

Böylece, finansman sisteminde gerçekleştirilen değişimle yapılan konutlarda yeni finansman projeleri ve yeni ihale yöntemleri uygulanarak, ülkenin toprak ve konut politikasına şekil verilmektedir. Yapılan kentsel dönüşüm ve finansman projelerinde yüksek rant getirisi olan kentsel topraklar tercih edilmektedir. Bu sistemde, kamu gücünden ve kamu kaynaklarından istifade edilerek toprakların konum rantına ek olarak sermaye yatırımına yönelik yeni rantların ortaya çıkması sağlanmakta, söz konusu kentsel topraklar projeler aracılığıyla imara açılmakta ve altyapı yatırımları da maliyet olarak kamu kaynaklarından karşılanmaktadır. Oysa, kamu kaynaklarının gereksiz tüketilmemesi bu alandaki temel anlayış olmalıdır. Kamunun zaten kıt olan kaynaklarının bu yolla eritilmesi doğru değildir. Dolayısıyla, rantı olmayan kentsel dönüşüm 
projelerinin, kamu kaynakları ile finanse edilmesi kamu ekonomisi için kötü bir tercihtir ve son çare olmalıdır.

\section{Kamu Mülkiyetinin ve Kentsel Planlamanın Rant Algısına Etkisi}

Kentlerdeki rantların ortaya çıkışı ve paylaşımı sürecinde kamu mülkiyetinin ve kent planlamanın rolü de önemli bir yer tutmaktadır. Bu çerçevede kentlerde var olan kamu mülklerinin satış1, özelleştirilmesi ve planlanması süreçlerinin kentsel rantın bölüşüm ve paylaşımı üzerinde meşrulaştırıcı bir rolü de bulunmaktadır. Ancak, bu uygulamalarla yaratılan yeni haklar ile oluşan rant değeri, yolsuzluk algısına yeni bakış açısı getiren bir algıya dönüşebilmektedir (Kahraman, 2010: 63)

Kamu mülkiyeti ve kentsel rantlara ilişkin politikalar dünyada içinden geçilen ekonomik anlayış ve siyasi rüzgârlardan bağımsız değildir. Yaşanılan dönem, piyasa ekonomisinin sermaye birikim süreçleri üzerinde belirleyici olduğu bir aşamayı göstermekte ve merkezi devlet yapılanması da, bu dönemin gerekliliklerinden hareketle organize olarak yeni politikalar üretmektedir. Hâkim paradigmanın, kentsel alanlardaki pratikleri de bu bakış açısının kentleşme süreçlerine yansıması olarak gözlenmektedir. $\mathrm{Bu}$ perspektiften yerel yönetimlerin kentsel mekânlara bakışı ve bu mekânlar üzerindeki kamu mülklerini ele alışı, girişecekleri yeni kamu yatırımlarına kaynak imkânı sağlayacak mülkler biçiminde olmaktadır.

Öte yandan devlet örgütlenmesinin yeniden yapılanması süreci içerisinde, kamu yönetiminin yereldeki görevlerini üstlenerek genişleten yerel yönetimlerin, bu kapsamda kentsel mekân ve yapılar üzerindeki işlevleri daha da öne çıkmıştır. Bunlardan özellikle planlama yetkileri ile kentsel rantların bölüşümü üzerindeki rolleri dikkate değer hale gelmiştir. Yapılan mevzuat değişiklikleriyle yeni işlevlere ve yetkilere sahip olan yerel yönetimler, ekonomik ilişkilerini düzenleme konusunda elini güçlendirecek imkânlara kavuşmuşlardır. Hizmetlerinin arzında piyasa ekonomisinin gereklerini uygulamaya dökecek yeni yöntemler, sermayeyle ilişkileri üzerinde belirleyici olmuştur. Yerel yönetimlerin planlama yetkisine kavuşması oluşabilecek rant karşısında rantı paylaşma konusunda toplumsal baskı ile karşı karşıya getirse de hizmet arzında ödeten beri sıkıntı duyulan kaynak temininde önemli bir kaynak olarak kullanılabileceğini göstermiştir.

Dar anlamda imar uygulamaları olarak da ifade edilen planlama ve plan değişiklikleri, rantın oluşum ve bölüşüm süreçlerindeki en önemi araçlardan biri olagelmiştir. Kentsel topraklarda ortaya çıkan söz konusu rantlar, planlamaya ilişkin alınan kararlardaki yanlışların bir sonucu olduğu kadar aynı zamanda nedeni olarak da değerlendirilebilir. Kentsel planlamanın özelleştirme işleviyle şekillenen yenilenmiş boyutu, kamu mülkleri üzerinde rant oluşumunu kolaylaştırıcı ve imar haklarının imtiyazlı dağıtımıyla da değerini arttıran bir görünüme kavuşmuştur.

Türkiye'de gerçekleşen kentleşme sürecinde kentsel rantın düzenlenmesine ilişkin yasal ve yönetsel araçları içerisinde sermayenin yeniden üretimi kapsamında öne çıkan "planlama" işlevi, bu süreçte özellikle imar planı değişiklikleri ve onaylama yetkileriyle yerel yönetimlerce etkili olarak yürütülmektedir. Kentsel mekânlarda imtiyazlı imar hakları oluşturulurken yönetsel amaç ve politik hedefler, kentsel rantların değerinin azami olarak arttırılmasına odaklanmaktadır. Bu ise planlamada olması gereken bütüncül yaklaşımın ve genel kamu yararının göz ardı edilmesine ortam hazırlamaktadır. Kamunun karar ve etkinlikleriyle değeri mümkün olduğunca arttırılan taşınmaz malların özel mülkiyet konusu olanlarının artan değerleri üzerinden alınan harcama katılma payları hizmetlere finansman katkısı sağlamakta mevcut veya kamulaştırmalarla elde 
edilen kamu mülklerinin piyasaya sermaye aktarımı özelleştirme satışları yoluyla gerçekleşmektedir. Yatırım, düzenleme, karar ve uygulamalarıyla kentsel mekânların, özel mülkiyetten kamu mülkiyetine tekrar özel mülkiyete yönelik değişim işlemi mülklerin değerinde ve menfaatin niteliği üzerinde etki yapmaktadır (Kahraman, 2010: 74-76).

Sosyo- ekonomik bir yönü olan kentsel planlamanın, piyasa sürecinin egemen olduğu bir dünyada sınırları belirlenmiştir. Kentlerde gerçekleştirilen imar planı düzenlemeleriyle kentsel mekânlar üzerinde değer oluşturma ve dağıtma aracı olarak işlev görmektedir. Bu yolla yapılan girişimler, ekonomik ve toplumsal anlamda önemli etkilere yol açmakta ve kentsel plan uygulamaları, kentte var olan üretim ve paylaşım ilişkilerini yeniden şekillendirmektedir. Planlama faaliyetlerinin kamusal yönü nedeniyle ekonomik karakterine daha çok kamunun ideolojik duruşu yansımaktadır. $\mathrm{Bu}$ çerçevede yapılan her plan kendi üretim ve paylaşım ilişkilerini düzenlerken, tek işlevi bu olmasa da kentsel arazileri mevcut değerlerinden yeni rant değerlerine yükseltme misyonunu yerine getirmektedir.

Oysa doğru yapılacak bir kentsel planlama ile uygulama boyutuna yönelik en önemli araçlarından biri olan kamu arazileri kullanılarak; kentsel gelişmelerin yönlendirilmesi; sağlıklı arsa üretiminin gerçekleştirilmesi ve toplumsal bir sübvansiyon sağlaması olarak üç temel rol gerçekleştirilebilir. Bu sayede planlama ile kamu arazileri üzerinden piyasa eğilimleri, kamu yaran ilkesi çerçevesinde yönlendirilmekte, yine plan çerçevesinde, kamu arazi stokundan, arsa ve konut piyasası yaratılması sağlanabilmektedir. Son olarak kent mekânlarında gittikçe daha belirgin bir biçimde ortaya çıkan toplumsal ve ekonomik farklılaşmayı dengeleme adına, planlama çerçevesinde kamu arazilerinin alt gelir gruplarının kullanımına açılması da toplumsal ihtiyacı karşılamaya dönüktür. Burada kamunun, sübvansiyon politikaları çerçevesinde kamu arazi stokundan maliyeti azaltıcı bir unsur olarak yararlanması söz konusudur. Bu sübvansiyon uygulamaları, bazen altyapılı arsa sağlama biçiminde, kimi bazen de, toplu konut uygulamaları biçiminde olabilmektedir.

Kentsel planlama uygulamalarında beklenenin aksine, planlama eliyle ve bu arazilere verilen imar haklarıyla sermaye yatırımları cazip hale getirilmektedir. Böylece, hem kentteki konumları ve sağlanan haklarla oluşan yeni değeri, hem de bu değer üzerinden yapılan satışlarla arazi sahiplerinin rantı daha da arttırılmaktadır. Öte yandan yeni mülk sahiplerine vergisiz ve kesintisiz aktarılan arazilerle devletin, kentsel mekânları düzenleme araçlarından olan kentsel planlama ile zararını daha da arttırmasına neden olmaktadır. Dolayısıyla, planlama halka inmekten öte kuralsızlığa zemin hazırlamakta ve piyasa odaklı uygulamalara imkân veren yeni bir rol üstlenmektedir (Güzey, 2012: 68). Özellikle 1slah imar planlarının açtığı yasal yolla güçlerini ve pazarlık paylarını arttıran yapsatçılarla bazı arsa sahiplerinin bu planları bir yatırım aracı olarak kullanabildikleri görülmektedir (Şenyapılı, 2014: 336).

Kentlerdeki kamusal araziler üzerindeki farklı grupların çıkar mücadelesinde sermayenin üstünlük sağladığı ortadadır. Bu konuda düzenleyici role sahip olan kamu otoritesi, daha çok bu işlevlerini sermayeden yana gerçekleştirmektedir. Böylelikle kendisinden beklenenin tersine mekân üzerindeki toplumsal farklılaşmaları daha da derinleştirici bir rol oynamaktadır (Kahraman, 2010: 79). Dolayısıyla, Türkiye'de gereği gibi sağlıklı kent planları hazırlanıp uygulanmasının önünde bu süreçler üzerindeki çıkar temelli değişimi sağlama yönünde siyasal baskılara açık olması engeli yer almaktadır. 
Kentsel rantları düzenleyip yöneten unsurlar olan merkezi yönetim, yerel yönetimler ile piyasanın en önemli aracı olarak öne çıkan kentsel planlama vasıtasıyla merkezi yönetim, bu alandaki yetkisi ile yatırım kararlarını kullanarak, mülkiyetindeki toprakların satılması, vasfının değiştirilmesi, tahsisi gibi yöntemlerle, bunların özel mülk haline dönüştürülmesine, kentsel rantların ortaya çıkmasına ve paylaşımına neden olmaktadır. Yerel yönetimler, özellikle belediyeler de, mevcut planlama yetkileri ile kentsel toprakları ihtiyaçlarına göre kullanımını düzenleyebilmektedirler.

1980'lerden itibaren gelişen neoliberal politikaların uygulayıcıları haline gelen yerel ve merkezi siyasi otoriteler, dönemin yabancı sermaye yatırımlarını teşvik söylemlerinin etkisiyle, özellikle yerli sermaye lehine kentsel mekândaki kullanım ve mülkiyet haklarını yeniden düzenlemişlerdir. $\mathrm{Bu}$ düzenlemelerle kentsel topraklar üzerindeki kullanım ve mülkiyet hakları sınıfsal anlamda aşağıdan yukarıya ve niteliksel olarak da kamusal mülkiyetten özel mülkiyete doğru gerçekleşmiştir (Güzey, 2012: 71). Bu yeni paradigmaya göre, gelişmiş ülkelerin deneyimlerinden ve gittikçe artan bilgi birikiminden yararlanılarak, planların güncel tutulabilmesi için, sıkça revizyona gidilmesi ihtiyacıyla, uzun vadeli ve geleneksel planlama anlayışı yerine esnek, kısa ya da orta vadeli planlama anlayışına geçilmiştir. Ayrıca, projeler ve parçacı yaklaşımlar planlama uygulamalarında öne çıkmış, 1990'lardan itibaren de arazi temelli kentsel gelişme için etkisi ve işlevi yetersiz bulunan geleneksel planlamadan stratejik planlama yaklaşımlarına geçilmiştir (Şengül, 2002; Taşan-Kok, 2011).

Söz konusu ekonomik ve yönetsel anlayış ve pratiklerdeki değişim sürecinde yönetimin tüm alanlarında görüldüğü gibi kentsel rantlar alanında da, özel sektör kuruluşları ve sivil toplum örgütleri, "piyasa" adı altında yeni bir ortak olarak yer almıştır. Bu yeni ortağın, kentsel toprakların yönetiminde planlama, yatırım ve karar alma süreçlerine artık doğrudan etkisi söz konusu olmaktadır. Planlama ve yatırım kararları kentsel topraklara değer kazandırmakta ve değerdeki bu artış, piyasanın karar alma süreçlerine etkisi ile doğru orantılı gerçekleşmektedir. Kentsel rantların yönetiminde piyasa olarak söz edilen ve imar alanında imtiyazlı haklar talep eden öncelikli aktörler; inşaatçılar, emlak sektörü, sanayi, turizm, eğitim, sağlık alanlarındaki yatırımcılar, gayrimenkul yatırım ortaklıkları, bankalar ve finansal kuruluşlardır. Piyasa, bu süreçte kararlar üzerinde etkili olarak kamu mülkiyetindeki toprakların bir taraftan özel mülkiyete dönüştürülmesini diğer taraftan ise menkul kıymete çevirerek mali açıdan önemli bir araç haline getirilmesini sağlamaktadır.

Kentsel alanların biçimlenmesinde ekonomik gelişmenin önemli role sahip olması, bir taraftan piyasa odaklı dönüşümü zorunlu kılarken, girişimcilik odaklı yönetişim anlayışı, kentsel aktörleri yeniden belirlemektedir. Bu güne kadar kamu yararı adına kentte söz sahibi aktörler olan yerel yönetimler ve plancılar kentsel alanın biçimlenmesinde artık girişimciliği etkin hale getiren bir role de sahiptirler. Bunları kamu yararından piyasa ortamına taşıyan bu yeni nitelik yeni görev tanımları ile artık piyasa firsatlarını değerlendirerek, özel sektörün en yüksek faydayı sağlaması hususunda yapabilirliğini belirleyecektir (Güzey, 2012: 66-67).

Kent planları kentlerin doğal gelişim seyrini önemli ölçüde etkilemektedir. Kentsel mekânlar üzerindeki konut, eğitim, sağlık, spor, kültür, tarım, ticaret ve sanayi işlevlerini şekillendirmekte fiziki ve ekonomik yönden kentsel gelişmenin yönünü ve kapsamını belirlemektedir. Kamunun ve özel kesimin sunacağı hizmet yatırımları açısından kent toprağının talebe bağlı kullanım niteliği 
değişerek, değeri de sürekli artmaktadır. Muhtemel değer artışları ekonomik fayda beklentisiyle taşınmaz mal malikleri açısından spekülasyon konusu olmaktadır ki bu durumun kaynağı rant olarak karşımıza çıkmaktadır. Kentsel planlamanın zaman içinde giderek bireysel çıkarların aracı haline dönüşmesinin önüne geçilerek planların kamusal çıkarı gözetebilmesi için odak noktasına kamu yararının oturtulması ve bunun ne şekilde uygulamaya geçileceği üzerinde durulmalıdır. Bu konudaki çabalar, aynı zamanda kentsel rantı olumsuz anlamda kamu yağma, talan, soygun, bireysel çıkar, kamusal mülkiyet alanlarının tahribi gibi algılanmasının önüne geçmeye dönük toplumsal bilinci güçlendirecektir. Böylelikle halk tarafından etkinlikle denetlenen kentsel planlama kararlarında, toplumsal değer ve ilkeleri gözeten bir kamu yararı anlayışı ile hizmetlerin ele alınması daha doğru, etkileyici ve sonuç alıcı olacaktır (Azrak, 2002: 1).

Kentsel planlama, kentsel sorunlara çözüm üretme noktasında kentsel gelişme süreçlerine bütüncül müdahale imkânları geliştirmeyi ve bunu denetleyip, yönlendirmeyi içermektedir. Ancak, gelinen noktada, kent planlamasının farklı kurumların yetki ve sorumluluğu altında bulunması, planlamada karar alma süreçlerinde bütüncül bakışın yitirilmesine neden olmaktadır. Gerçekleştirilen plan değişiklikleriyle imtiyazlı imar hakları oluşturulması, elde edilen imar hakkı ile ortaya çıkan maddi külfetlerin yeniden kamu tarafından üstlenilmesi dolayısıyla kamu zarara uğramaktadır. Bu nedenle, kentteki kamu arazilerinin imar hakları ile özel mülk haline geçişi sürecinde devlet, piyasa ekonomisi çerçevesinde rol alan önemli bir aktör haline gelmektedir. Ne yazık ki bu yeni rol, yozlaşmanın başka bir boyutu olarak; çıkar amacıyla kamu gücünün kullanımı biçimiyle kendini gösterebilmektedir. Kentsel arazilerin el değiştirmesi, plan değişiklikleri, özelleştirme uygulamalarıyla meşru bir kılıfa bürünmektedir. Devlet eliyle oluşan kentsel rantların sınırlarının net olarak tespitinin zorluğu ve kullanımından doğan faydasının adil bölüşümünün yapılamaması, topluma yozlaşma algısı olarak yansımaktadır.

Devletin bu sürecin odak noktasında yer alması, kent mekânı açısından düzenleyici işlev görmesi beklenirken, sözü edilen bu faaliyetleri bu işlevini ortadan kaldırmaya dönüktür. Diğer bir deyişle devlet, kamusal mülkleri üzerindeki düzenleyici işlevini satışlarla ortadan kaldırmakta ve kendi eliyle oluşturduğu rantı ve oluşan yeni değeri sermaye birikim sürecine yönlendirmektedir. Bu durum sonuçta, mekânsal toplumsal ve ekonomik sorunları daha da arttırmaktadır. Devlet, piyasa mekanizması içerisinde piyasada yer alan bütün aktörlerin tercihleriyle şekillenmesi gereken kentsel topraklar üzerindeki işlevleri kendisi yüklenerek toplumun ve sermayenin yeniden üretimine katkı sağlamaktadır (Harvey, 2003: 248-250).

Devlet, kentsel mekânlara yönelik yapmış olduğu yatırım ve özelleşmelerle kamu mülklerini sermayeye aktararak, sermaye birikiminin ve rant oluşumunun koşullarını oluşturmaktadır. Bu açıdan kamusal mülklerinin, satış yoluyla sermayeye aktarması sürecinde piyasada düzenleyici ve dengeleyici rol oynaması gerekirken daha çok sermayenin rant elde etme amaçlı spekülatif yöntemlerine katkı sağlamaktadır. Dolayısıyla devlet, sermaye rant çelişkisi içinde; piyasaya müdahale ederek sermayenin rant üzerinden yeniden üretimine imkan sunmaktadır (Keskinok, 2006: 191).

Bununla birlikte, Türkiye'de uygulanan arsa politikaları, oluşan piyasa talebi karşısında yetersiz kalmaktadır. Kentlerimizdeki arsa üretiminin yetersizliği, kentsel gelişim sürecinin önemli bir sorun alanı olan rant adaletsizliklerine, gecekondulaşmaya, spekülasyonun giderek daha da artmasına, kentsel hizmetlerin sunumunda verimsizliğe, yer seçim sorunlarına, sosyal donatı alanlarında eksikliğe ve neticede sağlıksız kentsel mekânların oluşturduğu düzensizliğe neden 
olmaktadır. Böyle bir gelişme içerisinde, eldeki kamu arazileri, kamu açıklarını kapatmakta kolaylıkla pazarlanıp satılabilecek bir mali kaynak olarak görülmektedir. Bu bakış açısıyla kentsel alanlardaki getiri potansiyeli olan tüm mülkler üzerinde, yapılan müdahalelerle rant talebinin yoğunlaşması sağlanmakta ve devletin yetkilerinin kullanılmasıyla özel menfaatin öne çıktığı ancak kamu açısından da kaynak yaratan bir piyasa oluşmaktadır.

Sonuçta, kentlerimizde, sosyal ve teknik altyapı hizmetlerindeki eksiklik uzun zamandan bu yana yoğun olarak hissedilmektedir. Kamu arazileri, kentlerimizdeki bu tür mekânsal eksiklikleri giderecek alanlar olarak planlanmalıdır. Rant elde etmek adına başvurulacak kullanımlar sosyal altyapıdaki eksiklikleri daha da arttıracaktır. Planlama çerçevesinde kamu arazilerinin, piyasa koşulları içinde konut ihtiyacını karşılayamayan alt ve orta gelirliler için sosyal amaçlı konut olarak tasarlanması olanakları arttırılmalıdır. Bu kapsamda kamu arazileri, yapılacak doğru planlama ile düzenli kent yapısının üretilmesinde önemli bir uygulama aracı olacaktır. Ancak bunun gerçekleşme koşullarından biri, plan dengesinin ortak kullanım alanları ile nüfus yoğunluğu ilişkisinin birbiriyle uyumunu sağlayacak biçimde; yani kentte yaşayan tüm insanların ihtiyaçlarına karşılık verecek ölçüde ortak yarar doğrultusunda kurulmasını gerektirir. Bugün, kentlerimizde, bu ilişki ne yazık ki yeter düzeyde sağlanamamaktadır. Kent yönetimlerinin yapacağı hizmetlerle her durumda ortaya çıkabilecek rantın, adil paylaşımını sağlayacak bir mekanizma kurulmadan ve bütçelerine önemli katkı sağlayacak alternatif gelir kaynaklarına kavuşturulmadan, kamunun içinde yer aldığ 1 spekülatif rant ilişkilerinin kentlerde yeniden üretiminin azalması veya ortadan kalkması mümkün görünmemektedir.

\section{4. Özelleştirme, Bölüşüm İlişkileri Açısından Kentsel Rantın Görünümü}

Kentlerde gerçekleştirilen özelleştirme uygulamalarında, kentsel planlama faaliyetlerinden yararlanılması, kamu mülkiyeti olgusu ile kentsel rant algısını birbirine yakınlaştırmıştır. Yapılan bu faaliyetlerle, daha önce değeri oldukça düşük olan alanların bile kentsel rant değerleri yüksek seviyelere çıkmaktadır. Oluşan rantların paylaşım süreçlerinin kamu yararına uygun olmayan biçimde gerçekleştirilmesi, kent yönetimlerinin bu yöndeki ekonomik nitelikteki politik kararlarının sorgulanmasına neden olmaktadır.

Ülkemizde özel mülkiyeti destekleyici politikalar, Cumhuriyetin kuruluşundan itibaren siyasal süreçlerin ekonomi politikalarıyla bağlantılı olarak ve etkileri görece farklılaşarak, günümüze kadar uygulanagelmiştir. Kamu açıklarını kapatma gayesine yönelik oluşturulan politikaların en son yasal düzenleme olan 24.11.1994 tarihli 4046 sayılı "Özelleştirme Uygulamalarının Düzenlenmesine ve Bazı Kanun ve Kanun Hükmünde Kararnamelerde Değişiklik Yapılmasına Dair Kanun" dur. Kanunun 1. maddesinde, amaç, "özelleştirme programına alınan kamu iktisadi teşebbüsleri ve bu kuruluşların mal varlıklarının satışı yoluyla ekonomide verimlilik artışı ve kamu giderlerinde azalma sağlamak" olarak belirlenmiştir.

Küresel boyutta uluslararası düzeyde yönlendirilen ekonomi politikaları doğrultusunda serbest piyasa mekanizmasının işleyiş düzeninin egemen olduğu anlayışın, çare olarak gördüğü çözüm “özelleştirme"dir. Devlet, artık kar ve rant güdüsüyle, mali yük olarak gördüğü mülkleri ve teşebbüsleri özelleştirme gayreti içerisindedir. İlk bakışta hazineyi rahatlatıp aynı zamanda kaynak oluşturması dolayısıyla olumlu algılanan bu süreç, esasında devletin ve Türkiye'deki piyasa mekanizmasının kent mekânına, planlamaya, düşük gelirli ve mülksüz kent toplumuna olumsuz 
yansımaları olacaktır. Kent ekonomisi rant ekonomisine, kent mekanı da en fazla rantın sağlanabileceği bir "araca" dönüşmüştür. Kent planlama olgusu ise imar mevzuatına ve imar planına indirgenmiştir.

Oysa kentler gelişim süreçlerinde gerek yeni değerler yaratılması gerekse bu değerlerin toplumun tüm kesimlerine aktarılmasında önemli işlevler yüklenmektedir. Uygulamalarda genel olarak bir spekülasyon aracı olarak yer alan kent toprağı, rant oluşumuna farklı biçimlerde katkı sağlamaktadır. Bu rantın toplumda sahip olacağı gruplar ise onların kurumsal yapıları tarafından belirlenmektedir (Tekeli, 2011: 45).

Devlet, kent mekânı üzerinde oluşan piyasaya müdahale etme imkânı sayesinde, kentteki farklı sosyo-ekonomik grupların varlığını, kentsel mekân üzerindeki rant baskısına karşı kollayabilmektedir. Nitekim TOKİ modeli ile elde edilen rantın farklı bölgelerde değerlendirilip kullanılması buna örnek oluşturmaktadır. Devletin kentteki düzenleyici rolü kamu mülkiyetinin kentsel mekândaki ağırlığı, üzerinden yürüyebilir. Ancak kentsel rant, kentte yaşayan paydaşların ortak yararına kullanılabilecekken yani sosyo-ekonomik eşitsizliklerin önlenmesine dönük bir araç işlevi görebilecekken, yanlış yönetimle eşitsizliği ve adaletsiz paylaşımı daha da arttırabilir. Hatta genel olarak görülen odur ki, kentsel mekânlardaki kamusal mülkiyetler üzerinden rant yaratma faaliyetleri, kentsel alanlardaki eşitsizliklerin daha da çoğalmasına etki yapmaktadır.

Devletin, kentteki düzenleyici rolünü etkin kullanarak, kamu mülkiyetindeki mekânlar üzerinden, özellikle düşük gelir gruplarını da önceleyerek konut ihtiyacının karşılanmasına katkıda bulunması temel ilkesi olması gerekir. Bu konuda devlet tarafından, kentteki kamusal alanların illegal kullanımları göz ardı edilip, imar aflarıyla meşrulaştırılması söz konusudur. Ayrıca devletin kent merkezlerinde yüksek getirisi olan kamu mülklerini satışı suretiyle oluşturduğu rantların, kentte yaşayan tüm kesimlere yönelik hak ve menfaat paylaşımı konusunda zaaf gösterdiği bir gerçektir. Kamunun kent ekonomisi üzerindeki oldukça çelişkili olan bu etkinliği, bizzat devlet eliyle oluşturulan kentsel rantların paylaştırılması sürecindeki popülizminin kentleşme politikaları üzerinde belirleyici rol oynamasına neden olmaktadır.

Devletin piyasa koşullarında hayata geçirdiği tercih ve yöntemler, bu sistem üzerindeki etkinliğini belirlemektedir. Bu bakımdan önemli olan husus, kentsel topraklar üzerinde düzenleyici işlev görmesi gereken devletin kentsel mekânda eşitsizliklerin temeli olan rantların oluşumundaki ana kaynak haline gelmemesidir (Kahraman 2010, 67). Ne var ki, Türkiye'de kamu, mülklerini birer kaynak yaratma aracı olarak görmüş ve bunlar üzerinden, kendi sermayesini oluşturan bir aktöre dönüşmüştür. Kentteki özelleşme sürecinde kamu mülklerinin satışı yoluyla gerçekleşen rantın bölüşümünde, en önemli ve belirleyici rolün devlete ait olduğu görülmektedir.

Kamu arazilerinin özelleştirilmesi üzerinden verimli bir mali kaynak yaratmanın tek yolu, kamuya yüksek düzeylerde gelir getirmesini sağlayacak bir kent planlama anlayışının benimsenmesine bağlı görülmektedir. Dolayısıyla, bu anlayıştan yola çıkılarak, kamu arazilerinin özelleştirilmesiyle, planların daha çok rant geliri getiren kentsel kullanımlardan oluşması sağlanmaktadır. Ancak bu durum, zaten yetersiz olarak üretilen sosyal altyapı hizmetlerinin sunumunu, daha da azaltacak bir planlama anlayışını geliştirmektedir. Ayrıca böyle bir planlama anlayışı, devletin kendi eliyle düşüntü yapmasını ve kentsel rantı doğrudan kendisinin 
paylaştırmasını da beraberinde getirmektedir. Sürecin sonunda devlet, toplumsal eşitsizlikleri doğrudan desteklediği bir konuma yerleşmiş olmaktadır.

Kentte yerel yönetimlerin yapacakları hizmet ve yatırımların standartlarının daha da iyileştirilmesi için gerekli olan bütçedeki yetersizlikler nedeniyle gündeme gelen kamusal mülklerin satışı ve özelleştirme uygulamaları kenti tüketici sonuçlara neden olmaktadır. Öte yandan bu yöntemler kamusal yarar kapsamında gerekli görülse bile, kamusal yararın özel yarara dönüşümüne daha çok hizmet etmektedir. Böylelikle kentsel alanlarda kamusal hizmetlerin üretildiği mekânlar daraltılmakta ve kamusal fonksiyonlar özelleşmektedir. Kamusal hizmet üretimi işlevinden uzaklaşan kentler, tüketimin ve sadece kentsel rantlarla ayakta kalan bir kent kültürünün mekânı haline dönüşmektedir (Keskinok, 2009: 75-76).

Sonuçta, kamu mülklerin özelleştirilmesi eylemleri, kentsel planlama üzerinde karar alma yetki ve görevlerine sahip tüm kamu kurumlarının gelecekteki uygulamalarına engel olan, kent ekonomisini, toplumsal yaşam1, rant kaynaklı bölüşüm ilişkilerini ve mekânsal gelişmeleri olumsuz yönde etkileyen bir nitelik taşımaktadır. Bu nedenle yapılması gereken en önemli şey, kamu arazileri üzerinde oluşturulan politikalarda kamu yararının gözetilmesidir. Ayrıca, uygulanacak politikalarda, bütüncül planlama anlayışı dikkate alınmalı; kamu arazileri ile elde edilecek menfaatlerin kamuya yeniden kazandırılması sağlanmalıdır. Dolayısıyla, kamu arazileri toplumun bir kısmı için değil, tüm toplumun istifadesine yönelik başvurulan planlama araçları haline dönüştürülmelidir. Bununla birlikte, kamu mülklerinin kentsel gelişmenin yönlendirilmesinde ve kent mekânlarının sağlıklı bir biçimde yeniden üretilmesinde etkinlik sağlayacak doğru kullanım politikaları yürütülmelidir.

\section{Kentsel Hizmetlerde Rantın Finansman Aracı Olarak Kullanılması}

Son yıllarda kentsel hizmetlere yönelik artan talep ve beklentilere karşılık yerel yönetimlerin mali yetersizlikleri yeni finansal arayışlar içerisine girmelerine neden olmuştur. Yerel hizmetlerin etkinlikle yürütülebilmesi için gerekli olan kaynaklara duyulan ihtiyacın mali boyutu ve yerel yönetimlerin kapasitesini aşan beklentiler nedeniyle hizmet odaklı çoğu teşebbüsün merkezi yönetime devredilmesi eğilimini son derece artmıştır. Oysa yerel yönetimlere mali özerklikleri bağlamında yapılması gereken, mali kaynaklarına yönelik daha fazla tasarruf hakkı verilmesidir (Egeli ve Diril, 2012: 25).

Yerel yönetim anlayışındaki dönüşümün odağında yer alan kentler aynı zamanda ekonomik gelişmenin de merkezinde yer alırlar. Bu süreçte kentlerin küreselleşmesiyle beliren söz konusu dönüşümün, bariz bir göstergesi olan sermayenin hareketliliği ve uluslararası alanda konumlarının iyileştirilmesine yönelik, etkin bir rekabete itildikleri görülmektedir. Ancak bu rekabette yerel yönetimler, daha iyi alt yapı imkânları sağlama ve daha kaliteli hizmetler üretebilme noktasında, giriştikleri yatırımları gerçekleştirebilmek için, uluslararası finans çevrelerinden edindikleri krediler nedeniyle, sermaye yapıları ile ilişkilerinde bağımlı hale gelmektedirler. Diğer taraftan, yerel yönetimlerin sunduğu kentsel hizmetler de sermayenin yeniden üretimine yönelik politikaların belirlediği alanlara kaymıştır. 
Ayrıca, Türkiye'de kentsel rantların ortaya çıkışında ve bu yöndeki algının şekillenmesinde önemli bir yere sahip olan yerel yönetimlerin sundukları hizmetlerin etkisiyle ortaya çıkan rant olgusundan bu hizmetlerin finansmanına yönelik istifade etmemesi düşünülemez. Nitekim sahip oldukları yetkilerle gerçekleştirdikleri görevler, sermayenin yeniden üretimine yönelik elverişli alt yapıyı mümkün kılmaktadır. Kentsel planlama ve altyapı yatırımları bu konudaki işlevsel alanlar olarak öne çıkmaktadır.

Bu kapsamda, özellikle belediyelerin alt yapı, ulaşım, toplumsal ve kültürel hizmetleri, çevre düzenlemesi ve kentsel dönüşüm projeleri gibi faaliyetlerinin sonucunda oluşan kentsel rantlar, etkin olarak kullanılabilecek bir gelir kaynağı olarak öne çıkmaktadır. Öyle ki, söz konusu hizmetlerle meydana gelen değer artışlarına paralel olarak, hızla artan kentsel rant alanları, önemli bir gelir kalemi potansiyeline dönüşmüştür. Ancak uygulamada görülen problemler sebebiyle günümüzde bu potansiyelden etkin ve verimli biçimde yararlanılamamaktadır. Bu konuda öne çıkan kamusal rantın vergilendirilmesi önerilerinin temelinde, mali özerklik bağlamında belediyelerce yapılan hizmetler nedeniyle oluşan rant gelirlerinin, mevcut vergi ve şerefiyelerle etkinliğini sağlayamadığı, daha çok vergi dışı kaldığı görüşü yer almaktadır. Kentlerdeki değer artışları, vergilendirmek suretiyle özellikle yerel yönetimlere finansman sorunlarının çözümünde gelir kaynağı sağlama ve de kentsel rantın adil paylaşımı bakımından önemli bir uygulama olabileceği önerilmektedir (Ökmen ve Yurtsever, 2010, 65).

Rant temelinde meydana gelen değer artışlarının bir kısmının kamu yararı doğrultusunda vergilendirilmesiyle haksız rekabet, haksız kazanç ve kirli ilişkilerin önlenmesi de hedeflenmektedir (Saraçoğlu, Pürsünlerli Çakar ve Çakır, 89). Ancak bu girişimle rantın meydana getirdiği değer artışının doğru ve şeffaf bir biçimde belirlenerek mülkiyet hakkının ihlaline firsat vermeyen makul ve vatandaşça kabul edilebilir bir vergi yükü oluşturması sağlanmalıdır. Ayrıca elde edilecek gelirin paylaşılması konusunda, hizmetleri yürütecek yerel yönetimler başta olmak üzere kamunun payı da dikkatle ele alınmalıdır.

Yerel yönetimlerin yetkilerinin genişletilmesi kapsamında, planlama yetkisi ve hizmetlerinin özelleştirilmesi yanı sıra dış borçlanma yetkileri kazanması ile sermayenin baskısına daha açık hale gelmiş olduğu değerlendirilmektedir. $\mathrm{Bu}$ dönemde ranta ilgi duyan çıkar grupları yerel yönetim yapıları etrafında baskı grubu oluşturarak rantın adil ve eşit olarak halka yansıtılmasında engel oluşturabilecek bir konuma yerleşmiş olduklarını da dikkate almak gerekir (Kahraman, 2010: 67).

Yerel yönetimler gerçekleştirdikleri yatırımlarla aynı zamanda ekonomik anlamda dışsallık oluşturmaktadırlar. Bu durum, yatırım alanlarının etrafında ortaya çıkan yeni bir ekonomik değer olarak şekillenmektedir. Böylece değişim, yatırımın çevresindeki mülklerin değerindeki artışın yanı sıra kullanım biçiminde de gerçekleşmekte ve rant oluşmaktadır. Kamu mülkleri üzerinden rant oluşturularak yeni değer üzerinden satış yoluyla kaynak oluşturulması yöntemi, işlevsel açıdan yerel yönetimlerin merkezî yönetim ile ortak metot ve hareket yöntemi benimsediği bir alan olarak görülmektedir. Genellikle kamulaştırma yöntemi ile ya da tarım arazisi vasfindan arsa haline dönüşümü sırasında kentsel karakter kazanmanın bir bedeli olarak düzenleme ortaklık payı şeklinde elde edilen bir süreç yaşanmaktadır. 
Kentin planlamalar çerçevesinde yürütülen dönüşüm süreci ve geliştirilmesi çabaları daha çok bütçe gelirlerinden sağlanan finansmanla gerçekleştirilmektedir. Bu açıdan yerel yönetimlerin faaliyetlerinin kapsamı ve etkinliği beklentiyi karşılamaktan bir hayli uzak kalmaktadır. Öz kaynakların arttırılması suretiyle elde edilecek finansman kaynağına daha çok ihtiyaç bulunmaktadır (Topal, 2004: 120). Vergilendirme yetkisinin yerel yönetimlere devri konusunda ülkemizde olduğu gibi daha çok tercih edilen yöntem vergi matrahının merkezi yönetim tarafından belirlenmesi ve bu sınırlar çerçevesinde yerel yönetimlerin vergi oranlarını belirlemesidir. Bu konuda özellikle yerel nitelikteki vergilerin kullanımına ilişkin finansal kaynak yöntemlerinin geliştirilmesine ihtiyaç bulunmaktadır (Egeli ve Diril, 2012: 38).

Kentsel planlama ve dönüşüm süreçlerinde, kamu otoritelerinin kararlarıyla ortaya çıkarılan ranttan, toplumdaki belli kesimlerin istifade etmesi, gelir ve menfaat paylaşımında adaletsizliğe bizzat kamu eliyle yol açılmasına neden olunmaktadır. Kent yönetimlerince rant olgusunu finansman sağlama amacıyla kullanımının halen yasal bir temele oturtulamaması, bu yönde alınan kararların ahlaki açıdan eleştirilmesine neden olmaktadır. Bu konudaki yapılacak objektif, adil, gerçek anlamda kamu yararını gözeten bir vergi düzenlemesi ile sağlanacak gelirlerin, biryandan kentin sosyal, ekonomik ihtiyaçlarının finansmanına katkı sağlarken, diğer yandan da rantın yol açtığı gelir dağılımı adaletsizliklerini gidermeye fayda sağlayacağı değerlendirilmektedir.

\section{Sonuç:}

Türkiye'deki kentleşme sürecinde, kentsel biçimlenmenin önemli bir faktörü haline gelmiş olan kentsel rantlar, temelde dünyadaki yeni ekonomik paradigma ve buna bağlı olarak gelişen kentsel hizmet anlayışından bağımsız düşünülemez. Sürecin belirgin bir özelliği olarak kentlerde ortaya çıkan rant olgusu, toplumsal beklenti ve taleplerin karşılanmasına yönelik yeni hizmet arzına finansman sağlamakta yetersiz kalan kamu bütçelerine ilave "kaynak", bir "çare" olarak işlev görmektedir. Ancak kentsel rantların güncel bir sorun haline gelmeleri esasında kötü yönetilmeleri sebebiyledir. Bunun da temelinde yatan, kamunun karar, uygulama ve hizmetlerinin ortaya çıkardığı değer artışlarının, toplumsal faydaya uygun olarak adil paylaşıma imkân verecek mekanizmalarla yürütülmemesidir.

Kentsel rantların yönlendirilmesinde merkezi yönetim, yerel yönetimler ve piyasa önemli rol oynamaktadır. Devlet, bu süreçte mülklerinin satışı, planlaması ve uygulamasıyla bizzat kendi eliyle toplumsal gruplar arasındaki çıkar mücadelesinin önemli bir aktörü haline gelmiştir. Asıl bu süreçteki işlevi ise, özel sektör ve sivil toplum unsurlarından oluşan ve ekonomik aktivitelerin merkezi durumundaki piyasayı düzenlemektir. Ayrıcalıklı yatırım kararları, planlama işlevi ve imar düzenlemeleri ile ekonomik süreci etkileyerek piyasa üzerinde belirleyici olmaktadır. Öte yandan yerel yönetimlerin de son yıllarda ekonomik ilişkileri düzenleme konusunda elini güçlendiren imkânlara kavuşmuş oldukları görülmektedir. Getirilen hukuksal düzenlemeler sonucunda sahip oldukları yeni işlev ve yetkilerle, hizmetlerinin arzında piyasa ekonomisinin gereklerini uygulamaya yansıtacak yeni yöntemler sayesinde, sermayeyle ilişkileri üzerinde belirleyici hale gelmişlerdir. Öte yandan yerel yönetimlerin yeni yetkileri onları sermaye ve çıkar grupların yer aldığı piyasanın etkisine daha da açık hale getirmiştir. Bu yetkiler oluşabilecek rantı paylaşma konusunda toplumsal baskı ile karşı karşıya getirse de hizmet arzında ödeten beri sıkıntı duyulan kaynak temininde önemli bir kaynak olarak kullanılabileceğini de göstermiştir. Piyasa ise, 
kendi mekanizması içerisinde yer alan aktörlerin tercihleriyle şekillenmesi gereken mülk değerlerinin yeniden paylaşılması işlevini, çıkara dayalı spekülatif ilişkiler üzerinden, sözü edilen diğer aktörlerin yetkilerinin yönlendirildiği bir ortama dönüşmüştür.

Devletin kente bakış açısının da biçimlendiği yeni ekonomik dönüşümde, kamunun kendine kaynak bulma isteği, odak noktasıdır. Kamu kurumlarının birçoğu yeni kamusal işlevleri nedeniyle mülklerini, satış veya tahsis yoluyla özele devretmeye yönelmiştir. Bu süreçte kamunun düzenleyici olarak kullandığı bir araç olan kentsel planlama ise söz konusu mülklerin değerini arttırmaya dönük bir rant aracı haline gelmiştir. Kentin geliştirilmesi ve bu kapsamda gerçekleştirilen planlama ve kentsel dönüşüm çalışmaları, artan nüfus yoğunluğuna bağlı olarak yeni yapılaşma faaliyetleri ve buna paralel olarak daha da artan hizmet talepleri artık yerel yönetimlerin mevcut bütçe gelirlerinden karşılanması mümkün olmayan finansman sorununu oluşturmaktadır. Bu nedenle, kentteki değer artışlarından kaynaklanan rant kazançları, dikkat çekmektedir. Yasal düzenlemelerle ve yönetsel kararlarla gerçekleşen kentsel müdahaleler, kamu arazilerinin niteliksel olarak dönüşümü ve kamusal kullanım alanlarının özelleştirilmesi uygulamaları, tüm bunların kent yaşamına ve topluma etkileri göz önünde tutulduğunda kentlerde oluşan rantlar konusunda, sosyal olarak adil bir paylaşımının sağlanması, bu noktada kamu yararını önceleyen ortak değerlerin savunulması ve zaten uygulamada bulunan bu hususun mali açıdan yeni vergi düzenlemeleri kapsamına alınması gereği öne çıkmaktadır.

Etik Standart ile Uyumluluk Çıkar Çatışması: Yazarlar herhangi bir çıkar çatışmasının olmadığını beyan eder.

Etik Kurul İzni: Bu çalışma için etik kurul iznine gerek yoktur.

Finansal Destek: Yoktur

\section{KAYNAKÇA:}

Aksoy, E., Güzey Kocataş, Ö.(2017). “Gecekondu Alanlarında Uygulanan Kentsel Dönüşüm Projelerinin Meşruiyet Zemini Olarak Yoksulluk Ve Suç”, Karadeniz Teknik Üniversitesi Sosyal Bilimler Enstitüsü Sosyal Bilimler Dergisi, Y1l: 7 Sayı: 14 / Aralık 2017, ss.275-295.

Akyıldız, N. A.(2020). "Kentleşme ve Kentsel Gelişim Bağlamında Açık Kamusal Alanların Sürdürülebilir Kentler Açısından Değeri” Millî Folklor 125, Bahar, ss. 188-201.

Alonso, W.(1968).Locationand Land Use-Towards a General Theory of Land Rent, 3. Bask1, Harvard University Presi, Cambridge, Massachusetts.

Azrak, A.Ü.(2002). “Kamu Yararı Kavramı ve Planlama”, Ulusal Fiziki Planlama Semineri, TMMOB Mimarlar Odası, 18-19 Ocak, Ankara, ss. 57-62.

Boratav, K.(2000).Yeni Dünya Düzeni Nereye, İmge Kitabevi, Ankara.

Ricardo, D.(1997).Ekonomi Politiğin ve Vergilendirmenin İlkeleri. (Çev. T. Ertan), Belge Yayınları. İstanbul. 
Dale, D., Johnson, W., Brzeski, J.(2001).Land Value Functions and Land Price Indexes in Cracow, 1993-1999, Journal of Housing Economics, Elsevier.

Doğan, H.H.(2015). "Yerel Yönetimlerin Kentsel Dönüşüm Uygulamaları Sürecine Halkın Katılımı”, Hitit Üniversitesi Sosyal Bilimler Enstitüsü Dergisi - Y11 8, Sayı 2, Aralık, s. 511, ss.505-543.

Egeli,H., Diril, F.(2012).“Türkiye'de Yerel Yönetimlerde Mali Özerklik ve Vergilendirme Yetkisi”, Sayıştay Dergisi, Sayı:84, Ocak- Mart, ss.25-44.

Ertürk, H.(1997).Kent Ekonomisi, Bursa: Ekin Kitabevi, 2. Bask1.

Ertürk, H., Sam, N.(2009).Kent Ekonomisi, Ekin Yayınları.

Evans, A.W.(1983).The Determination of the Price of Land. Urban Studies (20), ss. 119-129.

Göksu, E., Bal, E.(2010). “Türkiye’de Neo-Liberal Mekânsal Gelişim Stratejisi Olarak Kentsel Dönüşüm Projeleri”, Kentsel Dönüşümde Politika, Mevzuat, Uygulama içinde, (Der. Dilek Özdemir), Nobel, İstanbul, ss. 256-284.

Güzey,Ö.(2012).Türkiye'de Kentsel Dönüşüm Uygulamaları: Neo-Liberal Kent Politikaları, Yeni Kentsel Aktörler ve Gecekondu Alanları, İdeal Kent, Sayı 7, Eylül 2012, ss. 64-83.

Harvey, D.(2003).Sosyal Adalet ve Şehir (Çev. Mehmet Moralı), Metis Yayınları, İstanbul.

Kahraman, T.(2010). "Imar Uygulamalarında Gizli Yolsuzluk: Ayrlcalıklı Özelleştirmeler ve Kentsel Rant”, İş Ahlakı Dergisi, Kasım, C. 3, Sayı 6, ss. 61-80.

Kartal, K.(1977). “Kent Toprağında Özel Mülkiyet Hakkının Doğurduğu Sorunlar,” Amme İdaresi Dergisi, C. 10, No. 2, s. 25-28.

Keleş, R.(2000). “Kent ve Çevre Değerleri Bağlamında Kamu Yararı Kavramı”, Melih Ersoy \& H. (Der. Çağatay Keskinok), Mekân Planlama ve Yargı Denetimi içinde, Yargı Yayınevi, Ankara, ss. 1-14.

Keleş, R.(2013).Kentleşme Politikası, 13. Baskı. İmge Kitabevi, Ankara.

Keskinok, H. Ç.(2006). Kentleşme Siyasaları, Kaynak Yayınları, Ankara.

Keskinok, H. Ç. (2009). “Kenti Tüketmek Üzerine”, Mimarist, 33, ss. 74 -77.

Kutlu, Ö.(2004).Gelişmiş Ülkeler ve Türkiye’de Kamu Reformu ve Yönetimin Yeniden Düzenlenmesi, Nobel Yayın Dağıtım, Ankara.

Marx, K.(1999).Artı Değer Teorileri, İkinci Kitap. (Çev. Y. Fincanc1), Sol Yayınları. Ankara. 
Marx, K. (2006).Kapital, Üçüncü Kitap, (Çev. Alaattin Bilgi), Sol Yayınları, 5. Baskı, Ankara.

Miles, M., Berens, G.L., Meiss, M.A.(2000).The Raw Material: Land and Demographics in the United States, Real Estate Development Principles and Process, ULI.

Ökmen,M., Yurtsever,H.(2010).Kentsel Planlama Sürecinde Oluşan Kamusal Rantın Vergilendirilmesi, Maliye Dergisi, Sayı: 158, Ocak-Haziran, ss. 58-74.

Özgül, C.G.(2020).“Bentderesi'nin Mekânsal Bir Çözümlemesi: Kamusal Mekândan Kentsel Rant Alanına”, Kent ve Çevre Araştırmaları Dergisi, Haziran, Cilt:2, Sayı:1, ss.59-76.

Öztürk, M.(1992).Kentsel Toprak Rantı ve İstanbul'da Arsa Değerleri; Yüksek Lisans Tezi; İ.Ü. Sosyal Bilimler Enstitüsü, İktisat Ana Bilim Dalı, İstanbul.

Rosenthal, S.S., Helsley, R.W.(1994).Redevelopment and the Urban Land Price Gradient, Journal of Urban Economics, 35.

Sadioğlu, U.(2020).Türkiye'de Kentsel Dönüşümün Anlamı, Aktörleri ve Amaçları, İdealkent, Cilt 11, Sayı: 30, ss.878-908.

Saraçoğlu, F., Pürsünlerli, Ç.E., Çakır, M.(2015). "Rant Vergisi Ve Ülkemizdeki Tartışmalar”, Gazi Üniversitesi İktisadi ve İdari Bilimler Fakültesi Dergisi, Arşiv, Cilt 17, Sayı: 3, ss. 83-99.

Sevindik, S.(2009).“İmar Planlarıyla Oluşan Kentsel Rantın Kamuya Kazandırılması için Ülkemizde Kullanılan Araçlar”, Mahalli İdareler Dergisi, Sayı:175, Mart, ss. 53-64.

Şahin, S.Z.(2003).Imar Planı Değişiklikleri ve Imar Hakları Aracılı̆̆ıyla Yanıltıcı (Pseuda) Kentsel Dönüşüm Senaryolart: Ankara Altındă̆ İlçesi Örneği”, Kentsel Dönüşüm Sempozyumu, İstanbul.

Şengül, H. T.(2007). "Planlama Meslek Alanı ve Dönüşümü: Bir Çerçeve Önerisi”, 8 Kasım Dünya Şehircilik Günü 31. Kolokyumu, Planlama Meslek Alanı: Geçmişten Geleceğe Bildiri Kitabı içinde, Ankara, ss. 105-127.

Şengül,H.T.(2002). "Planlama Paradigmalarının Dönüşümü Ü̈erine Eleştirel Bir Değerlendirme”, Planlama Dergisi, 2 (3), ss. 8-30.

Şenyapılı, T.(2014). "Denetimsiz ve Adaletsiz Rant Paylaşımının Biçimlendirdiği Kentsel Dokuya Örnek: Ankara-Yıldız”, İdeal Kent, Say1: 11, Ocak 2014, ss. 326-347.

Şişman, A., Kibaroğlu, D.(2009). “Dünyada ve Türkiye'de Kentsel Dönüşüm Uygulamaları”, TMMOB Harita ve Kadastro Mühendisleri Odas1 12. Türkiye Harita Bilimsel ve Teknik Kurultayı, 11-15 Mayıs, Ankara. 
Taşan-Kok, T.(2011).Introduction: Contradictions of Neoliberal Urban Planning. Tuna Taşan-Kok \& Guy Baeten (Ed.), Contradictions of Neoliberal Planning Cities, Policies and Politics içinde (pp.1-20), Springer Science and Business Media, London/ New York.

Tekeli, İ.(2003). “Kentleri Dönüşüm Mekânı Olarak Düşünmek”, Kentsel Dönüşüm Sempozyumu, TMMOB İstanbul Şubesi Yayınları, İstanbul.

Tekeli, İ.(2011). Kent, Kentli Hakları, Kentleşme ve Kentsel Dönüşüm, Tarih Vakfı Yurt Yayınları, İstanbul.

Topal, A.(2004). "Belediyelerin öz gelirlerinin Arttırılmasında Vergilendirme Yetkisi: ülkelerarası Bir Karşılaşıtırma”, Karadeniz Teknik Üniversitesi, iktisadi ve İdari Bilimler Dergisi, Sayı: 3-4, C.18, ss.119-133.

Topçu, T.(2018). "Kent Topraklarl, Kentleşme ve Rant”, Anka Strateji Dergisi, http://ankaenstitusu.com/anka-strateji-dergisi-2/anka-strateji-dergisi-mart-nisan-2018/, ss. 36-39.

Topçu, T. (2017). "Kentsel Rant Tartı̧̧maları”, http://ankaenstitusu.com/anka-strateji-dergisi2/anka-strateji-dergisi-kasim-aralik, ss.46-47.

Turan, A.(2009). Türkiye'de Kentsel Rant Devlet Mülkiyetinden Özel Mülkiyete, Tan Kitabevi, 1. Bask1, Ankara.

Ulutaş, C.(2005).Kentsel Toprak Rantının Kamuya Kazandırılmasında Bir Araç Olarak İmar Haklarının Toplulaştırılması, (Dikmen Vadisi Örneği), Ankara Üniversitesi Sosyal Bilimler Enstitüsü Kamu Yönetimi ve Siyaset Bilimi Anabilim Dalı, Yüksel Lisans Tezi, Ankara.

Umay, M. A.(2006). "Kentsel Rantlar Nedeniyle Oluşan Gelirlerden Kamunun Pay Alması Gerekmez mi?’, Mali Kilavuz Dergisi, Sayı 31, Ocak-Mart 2006, ss. 108-111.

Yaman, F. T., Şahinbaş, U.(2017). İstanbul Aydın Üniversitesi, Anadolu Bil Meslek Yüksekokulu Dergisi, Say1: 47, ss.53 - 77.

Y1lmaz, O.K., Bozdoğan, R.(2018). “Türkiye’de Belediyelerin Mevcut Kentsel Dönüşüm Uygulamalarına Yönelik Tutumlart: İstanbul İlçe Belediyeleri Üzerine Bir Araştırma”, İdeal Kent, Say1: 24, C. 9, Y11: 2018-2, ss.430-455. 